\title{
Pengaruh Lama Perendaman dan Jenis Minuman Beralkohol Bir dan Tuak terhadap Kekerasan Email Gigi Manusia (In Vitro)
}

\author{
Malida Magista, Archadian Nuryanti, dan Ivan Arie Wahyudi \\ Bagian Biomedika Fakultas Kedokteran Gigi Universitas Gadjah Mada \\ JI Denta no 1 Sekip Utara Yogyakarta, Indonesia; e-mail: ivanocovic@yahoo.com
}

\begin{abstract}
ABSTRAK
Erosi gigi merupakan hilangnya lapisan email gigi karena asam. Jenis asam, pH rendah, serta kandungan kalsium, fosfat, dan fluoride pada bir dan tuak diduga merupakan faktor kimiawi penyebab erosi gigi. Tujuan penelitian ini untuk mengetahui pengaruh lama perendaman dan jenis minuman beralkohol bir dan tuak terhadap kekerasan email gigi manusia (in vitro). Penelitian ini menggunakan 14 sampel gigi premolar pertama atas. Setiap gigi dibagi menjadi 2 bagian, bukal dan palatal. kemudian dibagi menjadi 7 kelompok perlakuan, yaitu kelompok (A1) perendaman dalam bir (ringan); (A2) kelompok perendaman dalam bir sedang; kelompok (A3) perendaman dalam bir berat, kelompok (B1): perendaman dalam tuak ringan, (B2): perendaman dalam tuak sedang, (B3): perendaman dalam tuak berat dan kelompok kontrol (C). Uji kekerasan email gigi dilakukan menggunakan Micro Vickers Hardness Tester. Pengujian kekerasan awal email gigi dilakukan sebelum perendaman gigi. Perendaman gigi premolar pertama atas pada bir dan tuak dilakukan selama 10 detik, 50 detik, dan 250 detik perhari dengan penyimpanan subjek penelitian pada saliva buatan. Uji kekerasan akhir email gigi dilakukan setelah perlakuan selama 30 hari. Nilai perubahan kekerasan email gigi merupakan selisih nilai kekerasan akhir dan nilai kekerasan awal email gigi. Sebagai tambahan data, pada bir dan tuak juga diukur kandungan $\mathrm{pH}$, kalsium, dan fosfor. Data dianalisis menggunakan uji ANAVA dua jalur dilanjutkan dengan uji LSD Hasil analisis ANAVA dua jalur menujukkan bahwa jenis minuman dan lama perendaman berpengaruh bermakna terhadap kekerasan email gigi $(p<0,05)$. Hasil uji LSD menunjukkan adanya perbedaan rerata yang signifikan $(p<0,05)$ antar kelompok uji bir dan tuak. Kesimpulan dari penelitian ini adalah terdapat pengaruh jenis minuman beralkohol bir dan tuak dan lama perendaman terhadap kekerasan email gigi manusia (in vitro).
\end{abstract}

Maj Ked Gi. Juni 2014; 21(1): 47 - 55.

Kata kunci : bir, tuak, erosi gigi, kekerasan email, Vickers Hardness Tester

ABSTRACT: The Effect Of Contact Time And Alcohol Beverages Beer And Tuak On Human Dental Enamel Hardness (In Vitro). Dental erosion is the loss of dental hard tissue, associated with acid. Acid type, low pH, and concentration of calcium, phosphate, and fluoride are being estimated as chemical factors of dental erosion. The purpose of this study was to determine the effect of contact time and alcohol beverages beer and tuak on human dental enamel hardness (in vitro). This study was using 14 samples maxillary first premolar. Each tooth was divided into two parts, buccal and palatal. Then divided into 7 treatment groups, i.e. groups of light beer "drinkers" (A1), moderate beer "drinkers" group (A2), heavy beer "drinker" group (A3), light tuak "drinker" group (B1), moderate tuak "drinkers" group (B2), the group "drinkers" heavy tuak (B3) and control group (C). Enamel hardness values were monitored using Micro Vickers Hardness Tester. Initial enamel hardness value was tested before the treatment. Maxilla first premolar teeth were exposed to beer and tuak for 10 seconds, 50 seconds, and 250 seconds per day for 30 days in the presence of artificial saliva. Final enamel hardness value was monitored after 30 days of treatment. Enamel hardness difference values were calculated by subtracting initial and final enamel hardness value. As supporting data, It was measured $\mathrm{pH}$ and concentration of calcium and phosphor in beer and tuak. Data was being analyzed by two-way ANOVA and LSD test. Results showed that contact time and alcohol beverage beer and tuak had a significant influence to enamel hardness value $(p<0.05)$. LSD test showed that some groups had significant average difference $(p<0.05)$. It was concluded that contact time and type of alcohol beverages beer and tuak had effect on human dental enamel hardness (in vitro).

Maj Ked Gi. Juni 2014; 21(1): 47 - 55.

Keywords: beer, tuak, dental erosion, enamel hardness, Vickers hardness tester

\section{PENDAHULUAN}

Bir merupakan minuman beralkohol dengan tingkat konsumsi nomor 2 terbesar di dunia. Indonesia tercatat sebagai negara dengan konsumsi bir sebesar 100 juta liter pertahun. ${ }^{1}$ Tuak merupakan minuman berakohol tradisional masyarakat Sumatera Utara terutama Batak Toba dan Simalungun. Tuak berasal dari fermentasi nira pohon aren (Arenga pinnata). Tuak digunakan dalam upacara adat dan dikonsumsi dalam acara perayaan maupun aktivitas sehari-hari. ${ }^{2}$ 
Konsumsi minuman beralkohol dalam taraf sedang memberikan manfaat terhadap kesehatan tubuh seperti mengurangi resiko serangan jantung, aterosklerosis, stroke, dan kerapuhan tulang. Konsumsi minuman beralkohol yang berlebih dapat memberikan dampak buruk bagi kesehatan, seperti meningkatkan risiko penyakit kardiovaskular, penyakit hati, dan kanker hati. ${ }^{3,4,5,6}$ Pecandu alkohol memiliki insidensi menderita penyakit periodontal, karies, dan lesi oral prekanker yang lebih besar karena tingkat konsumsi alkohol yang terlalu tinggi. ${ }^{7}$

Erosi gigi merupakan hilangnya jaringan keras gigi yang berhubungan dengan asam ekstrinsik dan/ atau intrinsik yang berasal dari minuman/ makanan dan bukan karena bakteri. Erosi gigi yang terus terjadi akan berdampak pada hilangnya tinggi vertikal, masalah estetika, hipersensivitas pada gigi, dan memicu pembentukan dentin reaksioner. ${ }^{8,9}$

Email, lapisan terluar gigi, tersusun dari ion kalsium $\left(\mathrm{Ca}_{2}{ }^{+}\right)$, ion fosfat $\left(\mathrm{PO}_{4}{ }^{3-}\right)$, dan ion hidroksida $\left(\mathrm{OH}^{-}\right)$yang tersusun dalam hidroksiapatit $\left(\mathrm{Ca}_{10}\left(\mathrm{PO}_{4}\right)_{6}(\mathrm{OH})_{2}\right)$. Hidroksiapatit secara terus menerus mengalami demineralisasi dan remineralisasi. Selama proses demineralisasi dan remineralisasi terjadi secara seimbang, email gigi tidak akan hilang, sedangkan pada proses erosi gigi, proses demineralisasi lebih mendominasi dibandingkan proses remineralisasi. Reaksi kimiawi proses mineralisasi. ${ }^{10}$

$$
\mathrm{Ca}_{10}\left(\mathrm{PO}_{4}\right)_{6}(\mathrm{OH})_{2} \longleftrightarrow 10 \mathrm{Ca}^{2+}+6 \mathrm{PO}_{4}^{3-+}+2 \mathrm{OH}^{-}
$$

Bir yang memiliki $\mathrm{pH}$ rendah akan menurunkan kekerasan gigi. ${ }^{11} \mathrm{Bir}$ juga mengandung asam laktat dan asam sitrat. ${ }^{12}$ Jenis asam merupakan faktor yang berperan dalam proses erosi. Asam laktat dan asam sitrat dapat memperparah erosi gigi. ${ }^{13}$ Tuak mengandung $\mathrm{pH}$ rendah yang mengakibatkan penurunan kekerasan email gigi meskipun kandungan kalsium, fosfat, dan fluoride tuak dapat mengurangi proses demineralisasi pada waktu tertentu. ${ }^{14}$ Tujuan penelitian untuk mengetahui pengaruh lama perendaman dan jenis minuman beralkohol bir dan tuak terhadap kekerasan email gigi manusia (in vitro).

\section{METODE PENELITIAN}

Penelitian ini merupakan penelitian eksperimental laboratorium dengan desain penelitian Pretest Post test Control Group Design dengan subjek penelitian berupa gigi premolar pertama atas yang tidak mengalami karies dan fraktur serta tidak terdapat tumpatan pada gigi tersebut. Jumlah subjek penelitian 4 setiap kelompok. Empat belas mahkota gigi premolar pertama atas masing-masing dipotong menjadi 2 bagian bukal dan palatal, lalu dibagi menjadi 7 kelompok perlakuan, yaitu kelompok peminum bir ringan (A1), kelompok perendaman dalam bir sedang (A2), kelompok perendaman dalam bir berat (A3), kelompok perendaman dalam tuak ringan (B1), kelompok perendaman dalam tuak sedang (B2), kelompok perendaman dalam tuak berat (B3) dan kelompok kontrol (C). Subjek penelitian ditanam pada balok resin akrilik $(3 \times 3 \times 3)$ $\mathrm{cm}^{3}$ dengan bagian bukal atau palatal menghadap ke atas.

Penelitian diawali dengan menganalisis nilai $\mathrm{pH}$ dan kandungan kalsium dan fosfor bir dan tuak, kemudian dilakukan pengukuran nilai kekerasan email awal menggunakan Micro Vickers Hardness Tester. Penentuan titik identasi untuk mengukur kekerasan email gigi adalah di puncak tertinggi permukaan gigi. Beban yang digunakan $100 \mathrm{~g}$ selama 30 detik. Panjang diagonal indentasi diukur dan dimasukkan ke dalam rumus berikut. ${ }^{15}$

$$
N V H=\frac{1,854 \times P}{d^{2}}
$$

Ketrangan:

$$
\begin{array}{ll}
\mathrm{NVH} & \text { : Kekerasan sampel }(\mathrm{kg} / \mathrm{mm} 2) \\
\mathrm{P} & \text { : Berat beban }(100 \mathrm{~g}) \\
\mathrm{d} & \text { : Panjang diagonal }(1 / 1000 \mathrm{~mm})
\end{array}
$$

Perendaman gigi dalam bir atau tuak dibagi sesuai kelompok dengan lama perendaman 30 hari. Perendaman selama 30 hari bertujuan untuk mengetahui perubahan kekerasan gigi setelah 30 hari mengkonsumsi bir dan tuak. Penetapan lama perendaman gigi per hari diadaptasi dari klasifikasi frekuensi konsumsi alkohol per hari ${ }^{6}$ yaitu: a. peminum ringan $=0,29-6,21 \mathrm{ml}$ alkohol; $\mathrm{b}$. peminum 
sedang $=6,44-29,58 \mathrm{ml}$ alkohol; $\mathrm{c}$. peminum berat $=$ $>129,58 \mathrm{ml}$ alkohol.

Kandungan alkohol bir yang digunakan pada penelitian ini adalah $4,7 \%$, yang berarti dalam 1 liter bir terdapat $47 \mathrm{ml}$ alkohol. Lama perendaman gigi per hari diasumsikan sebagai durasi kontak minuman bir dan tuak pada email gigi selama 1 hari yang dihitung berdasarkan kandungan alkohol minuman dan volume minuman yang dikonsumsi oleh peminum ringan, sedang dan berat setiap harinya. Volume bir yang dikonsumsi dalam 1 hari dihitung menggunakan rumus berikut:

$$
\text { konsumsi } 1 \text { hari }=\frac{1 \text { liter bir } \times \text { volume akohol }}{47 \mathrm{ml} \text { akohol }}
$$

Berdasarkan perhitungan, volume konsumsi bir dalam 1 hari yaitu: a. peminum ringan $=6,2-132,1$ $\mathrm{ml}$; b. peminum sedang $=137-629,4 \mathrm{ml}$; c. peminum berat $=>635,5 \mathrm{ml}$. Durasi kontak minuman bir dan tuak pada email gigi selama 1 hari diadaptasi dari simulasi kondisi fisiologis ketika mengonsumsi minuman ringan yaitu 5 detik untuk setiap $32,5 \mathrm{ml}$ minuman. ${ }^{16}$ Durasi kontak/paparan minuman bir dan tuak pada email gigi selama 1 hari dihitung menggunakan rumus berikut:

$$
\text { paparan } 1 \text { hari }=\frac{\text { konsumsi } 1 \text { hari } \times 5 \text { detik }}{32,5 \mathrm{ml}}
$$

Durasi kontak/paparan bir pada email gigi dalam 1 hari yaitu: a. peminum ringan $=0,95-$ 20,32 detik; b. peminum sedang $=21,07-96,83$ detik; c. peminum berat $=>97,76$ detik. Lama perendaman subjek penelitian diambil dari nilai tengah dan perkalian 5 dari durasi kontak bir pada email gigi dalam 1 hari dari setiap kelompok. Lama perendaman subjek penelitian dalam satu hari yaitu kelompok bir $\mathrm{A} 1=10$ detik, $\mathrm{A} 2=50$ detik, dan $\mathrm{A} 3=250$ detik selama 30 hari. Lama perendaman kelompok tuak disesuaikan dengan kelompok bir karena tuak tidak memiliki persentase kandungan alkohol yang baku ${ }^{17}$, yaitu $B 1=10$ detik, $B 2=50$ detik, dan $B 3=250$ detik. Setelah perendaman dalam minuman selama 1 hari, subjek penelitian direndam dalam saliva buatan hingga perlakuan esok hari. Kelompok $\mathrm{C}$ hanya direndam dalam saliva buatan selama 30 hari.
Nilai kekerasan akhir email gigi diukur setelah 30 hari perlakuan. Lokasi titik identasi merupakan area yang sama dengan titik identasi uji kekerasan awal namun lokasi tersebut belum terdapat bekas titik identasi yang terdahulu. Nilai perubahan kekerasan email gigi didapatkan dari selisih nilai kekerasan akhir email gigi dengan nilai kekerasan awal email gigi.

\section{HASIL PENELITIAN}

Bir dan tuak memiliki $\mathrm{pH}$ rendah $(4,37$ dan 4,28 ) serta mengandung kalsium dan fosfor. Kandungan kalsium tuak $(113,67 \mathrm{ppm})$ jauh lebih tinggi dibandingkan bir (40,95 ppm). Kandungan fosfor bir $(218,06 \mathrm{ppm})$ lebih tinggi dibandingkan tuak (142,29 ppm).

Tabel 1. Nilai rerata perubahan kekerasan email gigi dalam VHN $(\mathrm{kg} / \mathrm{mm} 2)$

\begin{tabular}{lc}
\hline Kelompok & $\begin{array}{c}\text { Kekerasan email gigi } \\
\text { (rerata } \pm \text { SD) }\end{array}$ \\
\hline Kontrol & $11,29 \pm 3,46$ \\
bir ringan & $50,89 \pm 21,29$ \\
bir sedang & $84,93 \pm 36,99$ \\
bir berat & $130,28 \pm 29,22$ \\
tuak ringan & $40,98 \pm 23,31$ \\
tuak sedang & $145,82 \pm 41,76$ \\
tuak berat & $62,88 \pm 5,72$ \\
\hline
\end{tabular}

Tabel I menunjukkan hasil nilai rerata perubahan kekerasan email gigi berdasarkan jenis minuman dan lama perendaman. Nilai kekerasan email gigi kelompok kontrol mengalami perubahan meskipun tidak besar $(9,32 \pm 4,59 \mathrm{VHN})$. Perubahan kekerasan email gigi terjadi setelah dilakukan perendaman pada bir dan tuak. Nilai perubahan kekerasan email gigi kelompok peminum bir ringan $(50,89 \pm 21,29 \mathrm{VHN})$ dan peminum tuak ringan $(40,98 \pm 23,31 \mathrm{VHN})$ merupakan nilai perubahan kekerasan email gigi terendah. Perubahan kekerasan email gigi terbesar terjadi pada kelompok peminum bir berat $(130,28 \pm 29,22 \mathrm{VHN})$ dan peminum tuak sedang $(145,82 \pm 41,76 \mathrm{VHN})$. Kelompok peminum tuak ringan $(40,98 \pm 23,31$ VHN) dan peminum tuak berat $(62,88 \pm 5,72 \mathrm{VHN})$ memiliki nilai perubahan kekerasan yang hampir sama. 


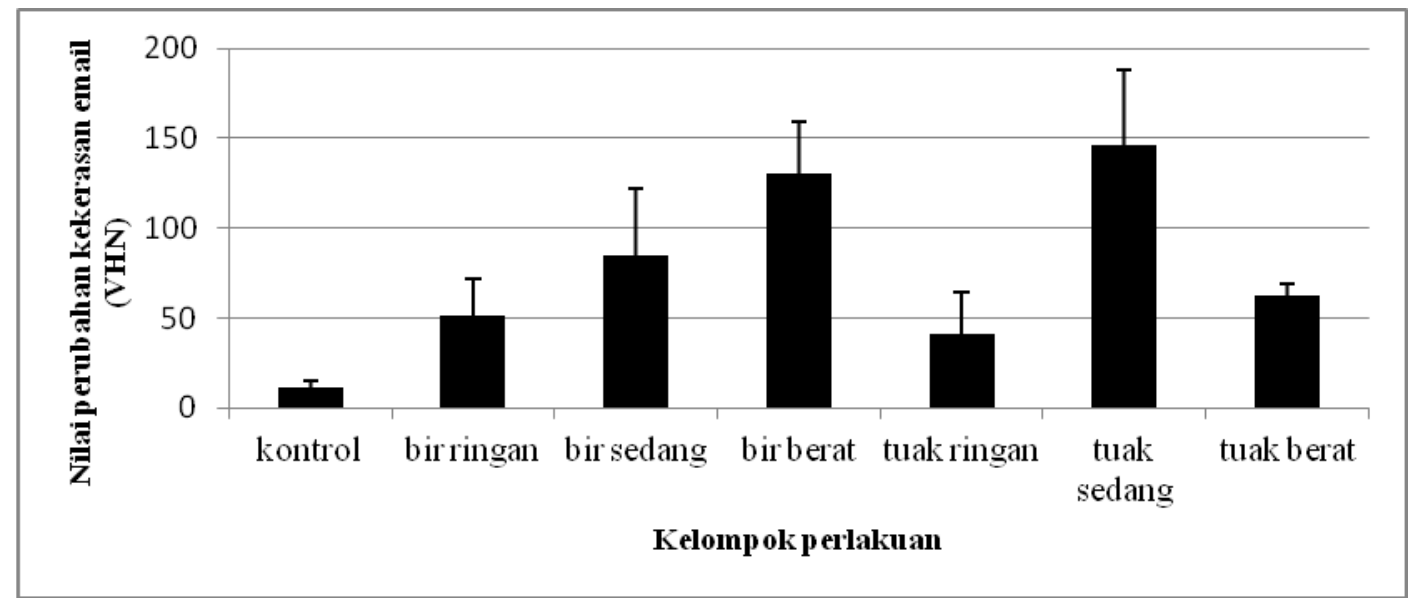

Gambar 1. Grafik nilai rerata perubahan kekerasan email gigi

Tabel 2. Hasil uji normalitas dan koefisien varians nilai perubahan kekerasan email gigi

\begin{tabular}{lcc}
\hline Kelompok & Koefisien varians $(\%)$ & Signifikasi $(\mathbf{p})$ \\
\hline Kontrol & 30,6 & $0,241^{*}$ \\
Bir ringan & 41,8 & $0,724^{*}$ \\
Bir sedang & 43,6 & $0,290^{*}$ \\
Bir berat & 22,4 & $0,295^{*}$ \\
Tuak ringan & 56,9 & $0,484^{*}$ \\
Tuak sedang & 28,6 & $0,991^{*}$ \\
Tuak berat & 9,1 & $0,900^{*}$ \\
\hline
\end{tabular}

Keterangan : ${ }^{*}=$ data normal $(p>0,05)$

Tabel 3. Hasil uji normalitas setelah transformasi data dan data rerata nilai perubahan kekerasan email gigi dalam VHN (kg/mm2) berdasarkan lama perendaman dan jenis minuman

\begin{tabular}{lcc}
\hline Kelompok & $\begin{array}{c}\text { Kekerasan email gigi } \\
\text { (rerata } \pm \text { SD) }\end{array}$ & Signifikasi $(\mathbf{p})$ \\
\hline Kontrol & $9,32 \pm 0,14$ & $0,231^{*}$ \\
Bir ringan & $50,89 \pm 0,20$ & $0,548^{*}$ \\
Bir sedang & $84,93 \pm 0,17$ & $0,644^{*}$ \\
Bir berat & $130,28 \pm 0,10$ & $0,308^{*}$ \\
Tuak ringan & $40,98 \pm 0,28$ & $0,510^{*}$ \\
Tuak sedang & $145,82 \pm 0,13$ & $0,872^{*}$ \\
Tuak berat & $62,88 \pm 0,04$ & $0,868^{*}$ \\
\hline
\end{tabular}

Keterangan : ${ }^{*}=$ data normal $(p>0,05)$

Grafik nilai rerata perubahan kekerasan email gigi (Gambar 1) menunjukkan perubahan kekerasan email gigi pada seluruh kelompok. Nilai kekerasan email gigi pada kelompok kontrol mengalami perubahan. Hal tersebut disebabkan karena pengukuran yang akurat sulit dilakukan pada permukaan gigi yang tidak rata ${ }^{18}$. Nilai kekerasan email gigi kelompok minuman bir menurun seiring dengan semakin lama durasi perendaman. Nilai kekerasan email gigi kelompok minuman tuak menurun, namun semakin lama durasi perendaman tidak mengakibatkan penurunan kekerasan yang semakin besar. Tingkat penurunan kekerasan gigi pada kelompok peminum tuak berat hampir menyamai tingkat penurunan kekerasan email pada peminum bir ringan dan peminum tuak ringan. 
Tabel 4. Hasil uji ANAVA dua jalur nilai perubahan kekerasan email gigi

\begin{tabular}{lc}
\hline Kelompok & Signifikansi \\
\hline Jenis minuman & 0,376 \\
Lama perendaman & $0,000^{*}$ \\
Jenis minuman dan lama perendaman & $0,011^{*}$ \\
\hline
\end{tabular}

Keterangan : * $=$ data signifikan $(p<0,05)$

Tabel V. Hasil uji LSD nilai rerata perubahan kekerasan email gigi

\begin{tabular}{|c|c|c|c|c|c|c|}
\hline & A1 & $\mathrm{A} 2$ & A3 & B1 & B2 & B3 \\
\hline C & $0,000^{*}$ & $0,000^{*}$ & $0,000^{*}$ & $0,000^{*}$ & $0,000^{*}$ & $0,000^{*}$ \\
\hline $\mathrm{A} 1$ & - & 0,070 & $0,002^{*}$ & 0,306 & $0,001^{*}$ & 0,313 \\
\hline A2 & & - & 0,100 & $0,007^{*}$ & 0,050 & 0,390 \\
\hline A3 & & & - & $0,000^{*}$ & 0,722 & $0,017^{*}$ \\
\hline B1 & & & & - & $0,000^{*}$ & 0,050 \\
\hline $\mathrm{B} 2$ & & & & & - & $0,007^{*}$ \\
\hline B3 & & & & & & - \\
\hline
\end{tabular}

Data penelitian terdistribusi normal $(p>0,05)$ namun tidak homogen $(p<0,05)$ sehingga dilakukan transformasi agar data terdistribusi normal dan homogen. Data transformasi terbukti terdistribusi normal dan homogen ( $p>0,05)$. Uji ANAVA dua jalur dapat dilakukan karena telah memenuhi syarat data terdistribusi normal dan memiliki varians yang sama.

Hasil uji ANAVA (Tabel IV) menunjukkan bahwa jenis minuman tidak berpengaruh bermakna terhadap kekerasan email gigi $(p>0,05)$, sedangkan lama perendaman berpengaruh bermakna terhadap kekerasan email gigi $(p<0,05)$. Uji ANAVA dua jalur menunjukkan bahwa jenis minuman dan lama perendaman berpengaruh bermakna terhadap kekerasan email gigi $(p<0,05)$. Berdasarkan hasil uji ANAVA dua jalur dapat disimpulkan bahwa hipotesis diterima. Uji post hoc LSD dilakukan untuk mengetahui signifikansi perbedaan rerata antar kelompok perlakuan yang ditampilkan pada Tabel V. Hasil uji LSD menunjukkan perbedaan rerata yang signifikan dengan $p<0,05$ pada beberapa kelompok uji.

\section{PEMBAHASAN}

Koefisien varians data nilai kekerasan email gigi berkisar 9,10-56,9\%. Koefisien varians dikatakan besar apabila lebih dari $30 \% .^{19}$ Varians tinggi nilai kekerasan email gigi disebabkan oleh beberapa faktor seperti komposisi kimiawi gigi, preparasi spesimen, dan variasi pembacaan panjang identasi, ${ }^{20}$ selain itu ketika gigi masih menjalankan fungsinya, berbagai faktor fisik dan kimiawi, seperti proses atrisi, abrasi, dan erosi, yang diterima gigi telah merusak jaringan keras gigi13 sehingga kemungkinan hal tersebut dapat menurunkan kekerasan email gigi.

Hasil uji ANAVA menunjukkan bahwa jenis minuman tidak berpengaruh bermakna terhadap kekerasan email gigi $(p>0,05)$. Bir dan tuak memiliki beberapa kesamaan karakteristik yang dapat mengubah kekerasan email gigi seperti faktor $\mathrm{pH}$ dan kandungan kalsium dan fosfor. 111,13,14,21

Asam merupakan keadaan kimiawi yang bersifat melepaskan ion hidrogen. ${ }^{22}$ Erosi gigi terjadi ketika ion hidrogen terlepas dan bereaksi terhadap kristal mineral gigi, kemudian hidroksiapatit pada permukaan kristal gigi akan larut dan menjadi ion $\mathrm{Ca}^{2+}, \mathrm{PO}_{4}^{3-}$, dan $\mathrm{OH}^{-}$. Mineral yang larut akan berdampak pada struktur prisma email yang menjadi tidak teratur dan diikuti dengan hilangnya ketebalan email gigi. ${ }^{10,11,19}$ Jenis asam bir juga memperparah penurunan kekerasan email gigi. Asam laktat dan asam sitrat bir merupakan chelating agents yang akan mengikat kalsium pada 


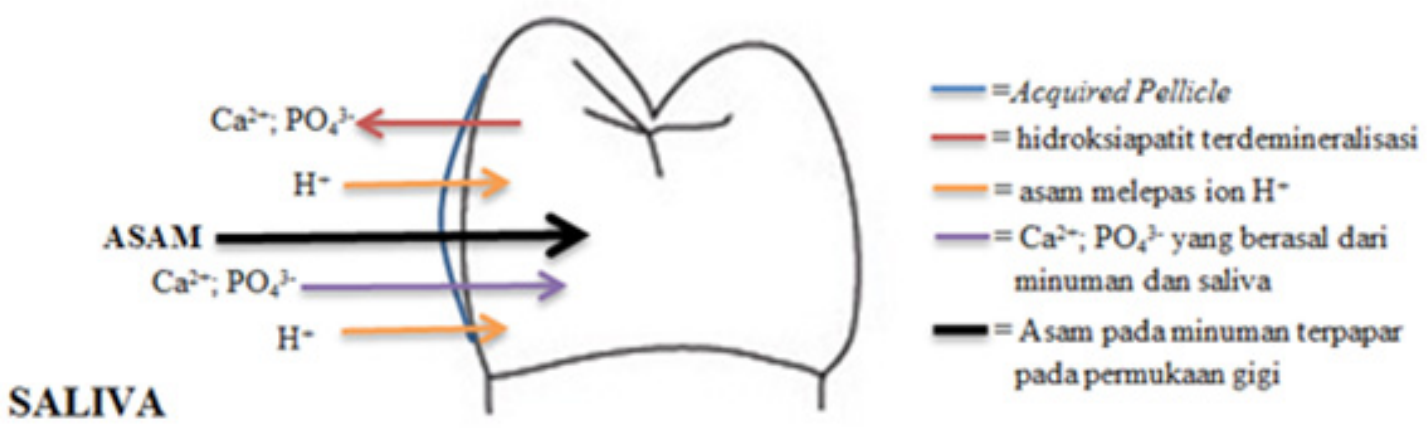

Gambar 2. Proses erosi gigi karena paparan asam

saliva dan mengurangi kemampuan saliva untuk melakukan remineralisasi pada permukaan gigi. ${ }^{13,21}$ Gambar 2 merupakan deskripsi proses erosi gigi yang terjadi ketika asam menyerang permukaan email berdasarkan penjelasan dari Stoker ${ }^{10}$ dan Higham. ${ }^{13}$

Hasil penelitian membuktikan bahwa bir dan tuak mengandung kalsium dan fosfor. Kalsium dan fosfor merupakan mineral yang penting dalam proses erosi. Kandungan mineral tersebut terbukti dapat mengurangi potensi erosif dari suatu minuman gigi. ${ }^{18}$ Proses pelarutan hidroksiapatit oleh proses erosi gigi dapat dikurangi dengan adanya kandungan ion kalsium dan fosfor. ${ }^{8}$ Proses remineralisasi akan terjadi ketika ion kalsium dan fosfor telah mencukup. ${ }^{23}$

Email gigi mengandung kristal hidroksiapatit akan mengalami proses demineralisasi dan remineralisasi secara terus menerus. Email gigi tidak akan hilang apabila proses demineralisasi dan remineralisasi terjadi secara seimbang, namun ketika proses erosi gigi terjadi, demineralisasi lebih mendominasi dibandingkan remineralisasi. ${ }^{10}$ Remineralisasi gigi dapat meningkat dengan adanya kandungan kalsium, fosfat, dan fluoride pada makanan dan minuman yang bersifat asam, ${ }^{9}$ sehingga diasumsikan bahwa kandungan ion kalsium dan fosfor pada bir dan tuak akan meningkatkan proses remineralisasi dengan menyediakan ion kalsium dan fosfor untuk proses presipitasi hidroksiapatit. Proses remineralisasi gigi meningkat dan penurunan kekerasan karena proses erosi gigi oleh paparan asam bir dan tuak berkurang.

Lama perendaman berpengaruh bermakna terhadap kekerasan email gigi $(p<0,05)$ pada uji ANAVA. Keparahan demineralisasi gigi karena proses erosi dapat terjadi karena kombinasi $\mathrm{pH}$ dan waktu kontak asam. ${ }^{24}$ Peminum bir yang mengalami penurunan kekerasan gigi yang semakin parah seiring dengan semakin lama durasi kontak bir pada permukaan gigi.

Perendamantuakringanmengalamipenurunan kekerasan gigi. Penurunan kekerasan email gigi terbesar terjadi pada perendaman tuak sedang (50 detik) sedangkan pada perendaman tuak berat (250 detik) terdapat penurunan kekerasan email gigi namun tidak sebesar penurunan kekerasan pada kelompok perendaman tuak sedang. Tingkat keasaman minuman tuak akan menurunkan tingkat kekerasan email manusia, namun pada periode waktu tertentu terjadi peningkatan kekerasan gigi, diasumsikan karena pada periode waktu tertentu pengaruh mineral dalam tuak lebih dominan dalam mempengaruhi proses remineralisasi email sehingga akan mengakibatkan meningkatnya kekerasan gigi. ${ }^{14}$

Tuak mengandung fluoride sebesar 1,0522 $\mathrm{mg} / \mathrm{l} .^{14}$ Penelitian ini tidak menganalisis kandungan fluoride sehingga volume fluoride pada tuak yang digunakan pada penelitian ini dapat berbeda. Fluoride dapat mengurangi tingkat penurunan kekerasan gigi. ${ }^{25}$ 
Fluoride dengan konsentrasi rendah dapat membantu proses remineralisasi dan menurunkan tingkat demineralisasi gigi ${ }^{25}$. Mineral gigi tersusun atas apatit berkarbonasi yang mengandung ion kalsium, fosfat, dan hidroksida dalam bentuk hidroksiapatit $\left(\mathrm{Ca}_{10}\left(\mathrm{PO}_{4}\right)_{6}(\mathrm{OH})_{2}\right)$. Ion hidroksida $\left(\mathrm{OH}^{-}\right)$dapat digantikan oleh ion fluoride $\left(\mathrm{F}^{-}\right)$dan membentuk kalsium fluoroapatit $\left(\mathrm{Ca}_{10}\left(\mathrm{PO}_{4}\right)_{6}(\mathrm{~F})_{2}\right)$ dengan proses. ${ }^{26}$

$$
\mathrm{Ca}_{10}\left(\mathrm{PO}_{4}\right)_{6}(\mathrm{OH})_{2}+2 \mathrm{~F}^{-} \longrightarrow \mathrm{Ca}_{10}\left(\mathrm{PO}_{4}\right)_{6}\left(\mathrm{~F}_{2}+2 \mathrm{OH}^{-}\right.
$$

Kalsium fluoroapatit merupakan mineral yang lebih stabil dan resisten dibandingkan kalsium hidroksiapatit. ${ }^{26}$ Fluoride akan bekerja efektif meskipun pada larutan yang memiliki $\mathrm{pH}$ rendah $(4,5-5,5) .{ }^{27} \quad$ Fluoride juga memerlukan waktu sebelum aktif dalam proses remineralisasi gigi. ${ }^{28}$

Penurunan kekerasan email gigi yang rendah pada perendaman minuman tuak selama 250 detik setiap hari selama 30 hari diasumsikan karena waktu kontak minuman yang cukup lama pada email gigi mengakibatkan kandungan kalsium, fosfor, dan fluoride memiliki waktu yang lama untuk melakukan proses remineralisasi di email gigi sehingga proses remineralisasi lebih dominan daripada proses demineralisasi gigi, selain itu, diasumsikan perendaman pada saliva buatan ikut berperan dalam proses remineralisasi gigi. Saliva buatan yang memiliki $\mathrm{pH}$ 6,8 diduga menaikkan $\mathrm{pH}$ gigi yang rendah akibat paparan asam dari minuman. Gigi dengan pH lebih dari 4,5 merupakan kondisi jenuh untuk terbentuknya flouroapatit $\left(\mathrm{Ca}_{10}\left(\mathrm{PO}_{4}\right)_{6} \mathrm{~F}_{2}\right)$ sehingga proses remineralisasi dapat terjadi dan proses demineralisasi dapat dikurangi. ${ }^{29}$

Uji ANAVA dua jalur menunjukkan bahwa jenis minuman dan lama perendaman berpengaruh bermakna terhadap kekerasan email gigi $(p<0,05)$. Bir menurunkan kekerasan email gigi dan penurunan kekerasan dipengaruhi oleh durasi kontak asam dari bir. Bir mengandung $\mathrm{pH}$ rendah dan memiliki asam laktat dan asam sitrat yang bersifat chelating agent yang menjadi faktor penyebab proses erosi gigi, ${ }^{11,12,13}$ namun, bir mengandung kalsium dan fosfor yang dapat mengurangi proses erosi. ${ }^{12,13}$ Tuak mengandung $\mathrm{pH}$ rendah yang dapat menurunkan kekerasan email gigi, namun pada periode waktu tertentu, mineral (kalsium, fosfor, dan fluoride) pada tuak dapat meningkatkan kekerasan email gigi. ${ }^{14}$

Proses erosi gigi tidak terlepas dari peran saliva dalam membantu remineralisasi email gigi. Saliva dapat mengurangi proses erosi gigi dengan menetralisir asam, membentuk pelikel, serta menyediakan kalsium, fosfat, dan fluoride untuk meningkatkan proses remineralisasi. ${ }^{18,30}$ Penggunaan saliva buatan bertujuan untuk menggantikan sebagian fungsi saliva alami yang berhubungan dengan proses remineralisasi meskipun tidak seluruh fungsi biologis saliva dapat tergantikan, seperti kemampuan saliva dalam pembentukan pelikel dan biofilm. Saliva buatan, meskipun memiliki kemampuan yang terbatas dibandingkan dengan saliva sesungguhnya, diharapkan dapat ikut berperan dalam menurunkan proses demineralisasi pada erosi gigi seperti yang terjadi dalam rongga mulut. ${ }^{31}$

\section{KESIMPULAN}

Terdapat pengaruh lama perendaman dan jenis minuman beralkohol bir dan tuak terhadap kekerasan email gigi manusia (in vitro). Minuman beralkohol bir dan tuak terbukti menurunkan kekerasan email gigi.

\section{DAFTAR PUSTAKA}

1. Kutanews. Konsumsi bir di Bali terbanyak nomor urut dua dunia. 2012. http://kutanews. com/2 0121205782/Kuta/Konsusmi-Bir-diBaliterbanyaknomor-urut-duadunia.html. diunduh 2/12/2012.

2. Ikegami S. Tuak dalam masyarakat batak toba: laporan singkat tentang aspek sosial-budaya penggunaan nira. Annual report of the University of Shizuoka. 1997. http://bambi.ushizuokaken .ac.jp/ kiyou4228021/11_3/11_3_5.pdf, diunduh 12/02/13.

3. Mann RE, Smart RG, Govoni R. The epidemiology of alcoholic liver disease, alcoholic liver diseas. 2003; 27(3): 209. 
4. Pandrea I, Happel KI, Amedee AM, Bagby GJ, Nelson S. Alcohol's role in hiv transmission and disease progression. Alcohol and HIV/ AIDS. 2010; 33(3): 203.

5. Bagnardi V, Blangiardo $M$, La Vecchia $C$, Corrao G. Alcohol consumption and the risk of cancer: a meta-analysis. Alcohol Res Health. 2001; 25(4): 263-70.

6. Dufour MC. What is moderate drinking? defining "drinks" and drinking levels. NCB. 1999; 23(1): 5-14.

7. Lund $A E$. Alcohol abuse, higher incidence of oral health problems linked. JADA. 2003; 134: 554.

8. Ren YF. Dental erosion: etiology, diagnosis, and prevention. 2011; Review, www.rdhmag. com, diunduh 04/01/2013.

9. Purkait SK. Essentials of Oral Pathology. Jaypee: New Delhi; 2011. h. 311.

10. Stoker HS. General, organic, and biological chemistry. Edisi enam. Belmont: Brooks/Cole; 2013. h. 103.

11. Panjaitan BR. Efek $\mathrm{pH}$ minuman teh botol, kopi, dan bir terhadap kekerasan permukaan gigi, Skripsi. FKG Universitas Sumatera Utara. 2010: http://repository.usu. ac.id/handle/123456789/1 9600, diunduh 26/2/2012.

12. Preedy VR. Beer in health and disese prevention. London: Elsevier; 2009. h. 213, 220.

13. Higham S. Caries Process and Prevention Strategies. Erosion. artikel. 2013; http:// www.dental care.com/enUS/dentaleducation/ continuingeducation/ce374/ce374.aspx?Mod uleName $=$ coursecontent $\&$ Part $I D=4 \&$ Section ID1, diunduh 2/3/2013.

14. Fadhilah D. Efek Minuman Tuak Terhadap KekerasanMikroEmailGigiManusia(Penelitian In Vitro), Skripsi. 2012; http://repository. unhas.ac.id/handle/123456789/2765, diunduh 12/02/2013.
15. Wachtman JB, Cannon WR, Matthewson MJ. Mechanical properties of ceramic. New Jersy; 2009. h.408.

16. Wongkhantee S, Patanapiradej V, Maneenut C, Tantbirojn D. Effect of acidic food and drinks on surface hardness of enamel, dentin, and tooth-coloured filling materials. Journal of Dentistry. 2006; 34: 214-20.

17. Zuhra W. Enjoying "tuak" in batak country. 2013; http://www.thejakartapost.com/news/ enjoying-tuak-batak-country.html, diunduh 12/02/2013.

18. Lussi A, Featherstone JDB. Understanding the chemistry of dental erosion. Monogr Oral Sci. 2006; 20: 66-76, 155.

19. Talyor SL, Payton ME, Raun WR. Relationship between mean yield, coefficient of variation, mean square error, and plot size in wheat field experiments, communications in soil science and plant analysis. 1999; 20(9-10):1439-47. (Abstr.).

20. Gutiérrez-Salazar MP, Reyes-Gasga J. Microhardness and chemical composition of human tooth. Material Research. 2003; 6(3): 367-73.

21. Oliver $\mathrm{G}$. The oxford companion to beer. New York: Oxford; 2012. h. 469.

22. Bamforth C. Beer tap into the art and science of brewing. New York: Oxford University Press; 2009. h. 133.

23. Hedge $M N$, Devadiga $D$, Jemsily PA. Comparative evaluation of effect of acidic beverage on enamel surface pre-treated with various remineralizing agents: An In vitro study. Journal of Conservative. 2012; 15(4): 351-6.

24. Eisenburger M, Addy M. Evaluation of $\mathrm{pH}$ and erosion time on demineralisation. Clinical Oral Investigations. 2001; 5(2): 108-11. (Abstr.).

25. Hughes PS, Baxter ED, Beer: Quality, safety, and nutritional aspects. The Royal Society of Chemistry. Cambridge; 2001. h. 99,105. 
26. Noble S. Clinical textbook of dental hygiene and therap. United Kingdom: Wiley-Blackwell; 2012. h. 225.

27. Cury JA, Tenuta LMA. Enamel remineralization: controlling the caries disease or treating early caries lesions? Braz. Oral. Res. 2009; 23(1): 23-30.

28. Cate JM. Review on fluoride, with special emphasis on calcium fluoride mechanisms in caries prevention. Eur J Oral Sci. 1997; 105(5): 461-5. (Abstr.).

29. Murakami C, Bönecker M, Corrêa MSNP, Mendes FM, Rodrigues CRMD. Effect of fluoride varnish and gel on dental erosion in primary and permanent teeth, Archieves of Oral Biology. 2009; 54: 997-1001.
30. Zero DT, Lussi A. Erosion-Chemical and Biological Factors of Importance to The Dental Practitioner. Internatonal Dental Journal. 2005; 55: 285-90.

31. Wang X, Mihailova B, Klocke A, Heidrich S, Bismayer U. Effect of Artificial Saliva on The Apatite Structure of Eroded Enamel, International Journal of Spectroscopy. 2011;http://www.hindawi.com/ journals/ijs/, diunduh 10/06/2013. 